Factors influencing Saudi Arabian Preparatory Year students' skills and attitudes in the use of mobile devices in learning English as a Foreign Language

\author{
Alshammari, Radhi $₫$ \\ University of New England, Australia (ralshamm@myune.edu.au) \\ Parkes, Mitchell \\ University of New England, Australia (mparkes2@une.edu.au) \\ Adlington, Rachael \\ University of New England, Australia (radlingt@une.edu.au)
}

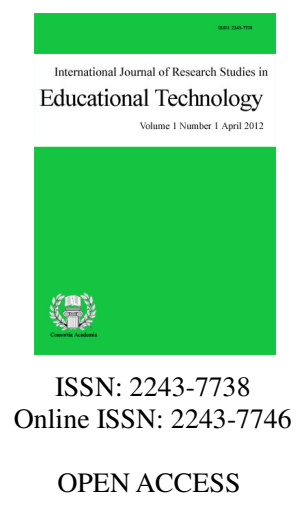

Abstract

The value of mobile devices for English Foreign Language (EFL) learning in tertiary contexts is well established. Most students own mobile devices making their use in EFL teaching a valid option. However, little is known about the factors influencing student skills and attitudes towards using mobile devices, which are important to understand when using them as a learning tool. The present study surveyed Preparatory Year students about their mobile devices skills and attitudes for EFL learning at a university in Saudi Arabia. Results demonstrated mobile device ubiquity and popularity, and a preference for mobile devices over computers for EFL learning amongst students. Student age, Preparatory Year path and level of English studied did not significantly influence student level of mobile device skills, attitudes towards using mobile devices in EFL learning, or future intention to use mobile devices in EFL learning. Place of residence (urban or rural) however, was shown to influence mobile device skills, attitudes towards using mobile devices in English language learning, and future intention to use mobile devices in English Language learning. While the majority of students at the study site are device ready, willing and able to engage in mobile technology-mediated EFL learning, there still remains the need to bridge skill and attitudinal gaps amongst students in order for mobile devices to be used to their full potential.

Keywords: English as a Foreign Language; mobile learning; student attitudes; higher education; preparatory year 


\section{Factors influencing Saudi Arabian Preparatory Year students' skills and attitudes in the use of mobile devices in learning English as a Foreign Language}

\section{Introduction}

Proficiency in the English language has become necessary owing to its global reach in terms of research, trade and business around the world (Almarwani, 2011). In response, many Saudi universities have adopted studies of English as part of foundation or Preparatory Year curriculum. Mobile devices, especially for the use of SMS messaging, have emerged as powerful tools for English as a Foreign Language (EFL) learning (Cavus \& Ibrahim, 2009; Levy \& Kennedy, 2005; Librero, Ramos, Ranga, Triñona, \& Lambert, 2007; Lu, 2008; Saran, Cagiltay, \& Seferoglu, 2008). At the same time, tertiary students have adopted mobile phones for informal language learning (Clough, Jones, McAndrew, \& Scanlon, 2008; Comas-Quinn, Mardomingo, \& Valentine, 2009), and among Saudi EFL students, the use of mobile devices is the most widespread means of communication outside of the classroom (Al- Shehri, 2012). As such, choosing to introduce mobile devices for English language learning seems a straightforward choice. However, institutions considering using mobile devices in this way must consider the appropriateness of the technology in their context and for their particular students. Positive student attitudes towards mobile devices is one important factor in the adoption of mobile technology for learning but student attitudes may be influenced by demographic and other factors (Qudah, Hussain, \& Al Matari, 2013). Consequently, in order to gain a fuller understanding of student attitudes one must also consider the factors that influence these attitudes in the first place.

This study sought to explore factors that might influence Preparatory Year students' skills and attitudes towards the use of mobile devices in EFL teaching and learning at a university in the central-north of Saudi Arabia. The university, located in a major city which itself is located in a rural area, enrolls students from both urban and rural locations. The university therefore provided a good opportunity to explore whether place of residence (i.e., urban or rural) had any influence on student skills and attitudes towards the use of mobile devices in EFL instruction.

Background - All Saudi universities have a Preparatory Year program to help bridge the gap between the public-school system and the undergraduate system (Yushau, \& Omar, 2007). The main goal of a Preparatory Year program is to improve the knowledge and skills of secondary school graduates before they undertake their chosen majors at university. The Preparatory Year also offers an appropriate atmosphere that allows students to settle into the new university learning environment. Preparatory Year students are expected to develop knowledge and skills across a range of subjects to prepare them for the world of university. One of these skills is proficiency in English. It is essential for students to develop their English because of the greater demands for English proficiency at the Tertiary level. Students from the Preparatory Year English program at the university were the population for this study.

\section{Literature Review}

The value of mobile technology for English learning in tertiary contexts has been well established (Alshammari, Parkes, \& Adlington, 2017). In particular, mobile devices are having an increasingly important role in English learning (Kukulska-Hulme, 2009; Stockwell, 2010). However, the capacity for rurally-located universities, or those which service rural students, to take advantage of technology is potentially hampered by the persistence of the digital divide between urban and rural students, and urban and rural universities. While the availability of the Internet has increased significantly over time, rural areas still lag behind urban areas in terms of access to the Internet (Haight, Quan-Haase, \& Corbett, 2014). Despite this, rural users favor Internet-based activities such as email, where urban users report higher levels of mobile device-based online activities (e.g., SNS, IM and file sharing) (Hong, Zhou, Fang, \& Shi, 2017; Park \& Kim, 2015). 
Factors influencing Preparatory Year students' skills and attitudes in the use of mobile devices in EFL

The provision of new Internet services has either slowed down or stabilized in developed countries (Pénard, Poussing, Zomo Yebe, \& Ella, 2012), which is perhaps one reason the digital divide persists within developed countries. In contrast, the roll out of mobile phone technology is far outstripping Internet provision largely due to market forces; especially in developing countries. Mobile technology is affordable and easy to use, even by people with low levels of technological skill and English proficiency. This means mobile devices are being adopted by more people in more sectors of the community compared with Internet access and computers (Pénard et al., 2012). As mobile devices coverage in developed countries moves towards saturation point, it makes sense to leverage the increasing availability of mobile technology for English learning in tertiary settings rather than having to rely on sub-optimal Internet services. Further, the ease of use and affordability of mobile devices makes the decision to use mobile technology for learning even more attractive.

Student attitudes using mobile technologies as a learning platform for the specific purpose of English as a Foreign Language (EFL) instruction is quite well represented in the literature (e.g., Chen, 2016; Saidoni \& Bahloul, 2016; Uzunboylu, Hürsen, Özütürk, \& Demirok, 2015; Viberg \& Grönlund, 2013; Wang, Chen, \& Fang, 2011). The integration of m-learning activities into the traditional EFL classroom is well received, and students report the learning process is interesting and effective and inspires them to learn the English language (Wang, et al., 2011). Although few studies have examined the Saudi Arabian context, similar attitudes have been expressed and Saudi student attitudes are positive towards the use of mobile devices (Khrisat \& Mahmoud, 2013). Further, many Saudi students believe that the use of mobile devices can help them to improve their skills in English (Nalliveettil \& Alenazi, 2016). However, the intention to adopt mobile learning can be curtailed by the skill sets students might bring to mobile learning tasks. For example, both basic ICT skills and advanced mobile skills play important roles in the intention of students to adopt mobile learning (Mac Callum \& Jeffrey, 2013).

Overall, university students' attitudes towards the use adoption of mobile technology have been positive. In the EFL context, student attitudes were similarly positive towards the use of mobile devices to specifically support their learning of English. However, given the importance of the Preparatory Year in the Saudi Arabian Higher Education system, still very little is known about what factors might influence Preparatory Year students' attitudes towards the use and adoption of mobile devices to support their English language learning. Further, despite the persistence of the digital divide, few, if any studies have examined place of residence or rurality as an influencing factor.

\section{Method}

\subsection{Study aim}

The aim of the study was to identify factors that might influence Preparatory Year Students in three target variables associated with the use of mobile devices in English language learning:

Level of mobile device skill;

Attitudes towards using mobile devices in English language learning;

Future intention to use mobile devices in English language learning.

A range of factors and the influence they might have on the target variables were considered:

Demographics (age and place of residence);

Level of computer skill and level of Internet skill;

Level of English studied

Academic pathway

Attitudes towards ICT and attitudes towards English. 


\subsection{Study context}

The research was conducted at an all-male university in the central-north of Saudi Arabia. The university, does not currently have a policy for the formal use of mobile devices in teaching and learning although these devices are used in an informal and ad-hoc basis (see, Alshammari, Parkes, \& Adlington, 2017). As is the practice in all sectors of the Saudi education system, male and female students are segregated. The university, located in a major city which itself is located in a rural area, services students living in both urban and rural locations. As a result, the university has elements of both rurality and urbanity. At the university there are three academic pathways in the Preparatory Year program: Medical Path, Humanities Path, and Science and Engineering Path. As part of their Preparatory Year studies, students are also expected to develop proficiency in the English language.

To support English language instruction, the university has an English Centre which provides an English intensive program for all students in the Preparatory Year. This program aims to improve students' communication in English for general and academic purposes. Students study two English courses across the two semesters of the Preparatory Year. Each of these two courses is delivered at four levels and students start at introductory or advanced levels depending on an initial placement test result. Students with low placement test results are expected to study all four levels of English in their Preparatory Year. Students with more advanced English commence study at a higher level and complete fewer levels.

\subsection{Study sample}

The study sample was drawn from male students enrolled across all the three academic pathways (Medical Path, Humanities Path, or Science and Engineering Path) in the Preparatory Year at the university. All students studied on campus and were enrolled in the English intensive program with all four levels of English being represented in the study sample.

\subsection{Data collection}

Students were asked to complete a web-based, survey comprising two main parts. The first part of the survey collected demographic information about the study participants (age, place of residence, Preparatory Year path and level of English studied at time of survey). The second part involved a series of seven-point Likert scale items to determine students': ICT self-efficacy items; attitudes toward English; attitudes toward learning English; mobile learning perceptions and behavioral intention to use mobile devices to support their English language learning. These survey scale items were modified from those used in previous studies (see, Mac Callum, 2011; Pollara, 2011).

\subsection{Data analysis}

Data from the web-based survey were analyzed in two ways. First, descriptive statistical techniques were used to obtain frequencies, means, standard deviation, and for reliability testing. Second, inferential statistical techniques were applied in the form of Pearson product-moment correlations, Independent-samples t-tests, and One-way Analysis of Variance (ANOVA) to determine if there were any statistically significant relationships between the various data items.

\section{Results}

\subsection{Demographics}

There were 425 valid student survey responses out of a study population of 2476 students giving a response rate of $17 \%$. For the purposes of the study, the required sample size for a margin of error of $5.0 \%$ and a 
Factors influencing Preparatory Year students' skills and attitudes in the use of mobile devices in EFL

confidence level of $95 \%$ was calculated to be 333 participants. Thus, the study sample size was considered to be within acceptable limits (Cooksey, 2007). The Preparatory Year path and age of respondents are presented in

Table 1.

Table 1

Age and Preparatory Year path of students

\begin{tabular}{lccccc}
\hline \multicolumn{1}{c}{ Path } & 18 years & 19 years & 20 years & 21 years and over & Total \\
\hline Medical Path & 5 & 16 & 5 & 3 & 29 \\
Humanities Path & 4 & 22 & 17 & 16 & 59 \\
Engineering and Science Path & 41 & 133 & 55 & 28 & 257 \\
Total & 50 & 171 & 77 & 47 & 345 \\
\hline
\end{tabular}

Respondents studied English at one of four levels (Level 1: low to Level 4: high). The level of English studied by students at the time of survey in each of the three Preparatory Year paths is provided in Table 2.

Table 2

Level of English and Preparatory Year path

\begin{tabular}{lccccc}
\hline \multicolumn{1}{c}{ Path } & Level 1 & Level 2 & Level 3 & Level 4 & Total \\
\hline Medical path & 16 & 7 & 8 & 4 & 35 \\
Humanities path & 53 & 6 & 8 & 2 & 69 \\
Engineering and Science path & 210 & 58 & 27 & 20 & 315 \\
Total & 279 & 71 & 43 & 26 & 419 \\
\hline
\end{tabular}

\subsection{Validity and reliability of scale items}

Construct validity was established through factor analysis with scale items loading according to the pre-defined survey structure. The internal reliability of the survey instrument was high, with an overall Cronbach alpha of .94. Values of Cronbach's Alpha for the respective scale items are given in Table 3. All values of Cronbach's Alpha were in the acceptable range of .6 to .8 (Cooksey, 2007).

\section{Table 3}

Values of Cronbach's Alpha for scale items

\begin{tabular}{lc}
\hline \multicolumn{1}{c}{ Scale } & Cronbach's Alpha \\
\hline Computer skills & .83 \\
Internet skills & .87 \\
Mobile devices skills & .95 \\
Student attitudes towards ICT & .80 \\
Student attitudes towards English & .79 \\
Student attitudes towards using mobile devices in English language learning & .82 \\
Future intention to use mobile devices in English language learning & .94 \\
\hline
\end{tabular}

\subsection{Mobile device ownership}

Table 4 provides the types of mobile devices owned by students. The majority of students (88.7\%) owned a smartphone reflecting the popularity of this device amongst the student population. The next most owned devices were cell phones with $22.6 \%$ of students reporting cell phone ownership. All students who owned smartphones also reported owning a cell phone. Only $8.9 \%$ of students $(n=38)$ owned cell phones but not 
Alshammari, R., Parkes, M., \& Adlington, R.

smartphones. Only $2.3 \%$ of students $(n=10)$ owned neither a smartphone nor a cell phone. The third most widely owned devices were Tablet PCs, and four of the ten students who owned neither a Smartphone nor a cell phone did, however, own a Tablet PC.

Table 4

Mobile device ownership

\begin{tabular}{lccc}
\hline \multicolumn{1}{c}{ Device } & Number of students & Sample Size & Ownership (\%) \\
\hline Smartphone & 377 & 425 & 88.7 \\
Cell phone & 96 & 425 & 22.6 \\
Tablet PC & 54 & 425 & 12.7 \\
Other & 12 & 425 & 2.8 \\
PDA & 6 & 425 & 2.1 \\
eBook Reader & 4 & 425 & .9 \\
\hline
\end{tabular}

\subsection{Skill using computers, the Internet and mobile device}

Students were asked to assess their skill in using computers, the Internet and mobile devices to carry out a range of activities. Skill levels were assessed using a seven-point Likert scale: 1. Never used, 2. Not very skilled, 3. Fairly skilled, 4. Skilled, 5. Moderately skilled, 6. Highly skilled, 7. Extremely skilled. A summary of results is presented in Table 5 .

\section{Table 5}

Student computer, Internet and mobile devices skills

\begin{tabular}{|c|c|c|c|}
\hline Computer Skills & & Mean & $S D$ \\
\hline To play digital audio files (e.g. iTunes) without accessing the Internet. & & 3.1 & 1.88 \\
\hline To create/edit audio and video. & & 3.2 & 1.80 \\
\hline \multirow[t]{2}{*}{ To manage/manipulate digital photos. } & & 3.2 & 1.79 \\
\hline & Overall & 3.2 & 1.58 \\
\hline Internet Skills & & Mean & $S D$ \\
\hline To make phone calls (e.g. Skype). & & 4.2 & 2.30 \\
\hline To use social networking software on the web (e.g. Facebook, etc.). & & 5.1 & 1.98 \\
\hline To look up reference information for study purposes. & & 4.6 & 1.79 \\
\hline To send or receive email. & & 4.7 & 2.08 \\
\hline \multirow[t]{2}{*}{ To buy or sell things (e.g. E-Mall, eBay). } & & 3.3 & 2.04 \\
\hline & Overall & 4.4 & 1.65 \\
\hline Mobile Skills & & Mean & $S D$ \\
\hline To text/SMS people & & 6.0 & 1.76 \\
\hline To call people & & 6.2 & 1.58 \\
\hline To download and play games or applications from the Internet & & 5.9 & 1.75 \\
\hline To send pictures or movies to other people & & 6.0 & 1.66 \\
\hline To play, and upload audio files (such as MP3 or the radio) & & 5.3 & 1.99 \\
\hline To access information /services on the web & & 5.6 & 1.82 \\
\hline To take digital photos/movies & & 5.7 & 1.87 \\
\hline \multirow{2}{*}{ To send or receive email } & & 5.2 & 2.09 \\
\hline & Overall & 5.7 & 1.58 \\
\hline
\end{tabular}


Factors influencing Preparatory Year students' skills and attitudes in the use of mobile devices in EFL

Comparison of the items in Table 5 shows higher means for student mobile device skills over both computer skills and Internet skills. This suggests that while students considered themselves to be skilled users of mobile technology, relatively speaking, they were not so confident about their skills using computers and the Internet. For mobile device skills, activities associated with communication (i.e., sending SMS, calling, and sending pictures or movies to other people) had the highest mean scores. Downloading and playing games and applications; taking pictures or movies; and accessing information and services from on the web were the activities with the next highest means.

\subsection{Student attitudes towards ICT}

Students were asked about their attitudes towards ICT in general. Student perceptions were assessed using a seven-point Likert scale: 1. Strongly disagree, 2. Disagree 3. Somewhat disagree, 4. Neither agree or Disagree, 5. Somewhat agree, 6. Agree, 7. Strongly agree. A summary of the results is presented in Table 6.

\section{Table 6}

Student Attitudes towards ICT

\begin{tabular}{lcc}
\multicolumn{1}{c}{ Item } & Mean & SD \\
\hline I enjoy learning and using new technology & 5.6 & 1.57 \\
I could probably teach myself most things I know about computers & 5.4 & 1.54 \\
I feel insecure about my ability to use ICT* & 3.2 & 1.87 \\
I find that I can quickly adopt new technology. & 5.1 & 1.73 \\
I can make the computer do what I want it to do & 5.6 & 1.62 \\
If I have a problem using the computer I can usually solve it & 5.0 & 1.69 \\
I am in complete control when I use a computer & 4.9 & 1.79 \\
ICT is difficult to use* & 3.4 & 1.80 \\
I enjoy working with technology & 5.2 & 1.78 \\
I need someone to tell me the best way to use a computer & 4.3 & 2.00 \\
ICT frustrates me* & 3.3 & 2.07 \\
& Orall & 4.9 \\
\hline
\end{tabular}

Note. * Reverse-coded item

Overall students held positive attitudes towards ICT. The survey items with the highest mean score were: I enjoy learning and using new technology (5.6) and I can make the computer do what I want it to do (5.6). This suggests that not only are students willing to adopt new technology, but also that they are reasonably confident of being able to use it. The next highest survey item was I could probably teach myself most things I know about computers (5.4). This could be considered as evidence of a reasonably high level of student autonomy when it comes to technology. The items with the two lowest means were ICT frustrates me (3.3) and I feel insecure about my ability to use ICT (3.2). Despite the relatively low means compared to the other survey items, nevertheless, $29 \%$ of students were in agreement (i.e., Strongly agree, Agree, Somewhat agree) with the statement ICT frustrates me while $27.4 \%$ of students were in agreement (i.e., Strongly agree, Agree, Somewhat agree) with the statement I feel insecure about my ability to use ICT. So, more than one quarter of students surveyed felt frustrated or insecure in their use of ICT.

\subsection{Student attitudes towards English}

Students were asked about their attitudes towards English. Student perceptions were assessed using a seven-point Likert scale: 1. Strongly disagree, 2. Disagree 3. Somewhat disagree, 4. Neither agree or disagree, 5. Somewhat agree, 6. Agree, 7. Strongly agree. A summary of the results is presented in Table 7. 
Alshammari, R., Parkes, M., \& Adlington, R.

Table 7

Student Attitudes towards English

\begin{tabular}{lcc}
\hline Item & Mean & $S D$ \\
\hline I find the English language interesting & 5.5 & 1.89 \\
I don't like speaking English* & 2.8 & 2.00 \\
I find the English language easy & 4.8 & 1.82 \\
I prefer the English language to the Arabic language & 3.7 & 2.11 \\
When I speak English, I feel that I'm more educated & 5.1 & 1.90 \\
I feel that learning English is useful for me & 5.6 & 1.86 \\
I dislike learning English* & 2.6 & 2.00 \\
I would rather spend my time on subjects other than English* & 3.4 & 1.94 \\
I feel that learning English is a waste of time* & 2.5 & 1.94 \\
When I leave university I shall give up learning English entirely* & 2.8 & 2.02 \\
\end{tabular}

Note. * Reverse-coded item

In general, students displayed positive attitudes towards English. The item with the highest mean was I feel that learning English is useful for me (5.6) followed by I find the English language interesting (5.5). The majority of students (56\% Strongly agree, Agree, or Somewhat agree) were in agreement with the statement, I find the English language easy. The two items with the lowest means were I dislike learning English (2.6) and I feel that learning English is a waste of time (2.5). Although, these two items had relatively low means, $19.5 \%$ of students were in agreement (i.e., Strongly agree, Agree, Somewhat agree) with the statement I dislike learning English while $18.8 \%$ of students were in agreement (i.e., Strongly agree, Agree, Somewhat agree) with the statement I feel that learning English is a waste of time. The item with the highest frequency of neither agree or disagree responses was I would rather spend my time on subjects other than English. Nearly one-quarter of students $(24.4 \%)$ were uncertain about this item. Two-thirds of students $(66.6 \%)$ of students were in disagreement (i.e., strongly disagree, disagree, somewhat disagree) with the statement, When I leave university I shall give up learning English entirely. Such a result might be considered as further evidence of positive attitudes towards English.

\subsection{Student attitudes towards using mobile technology in English language learning}

Students were asked about their attitudes towards using mobile technology in English language learning. Student perceptions were assessed using a seven-point Likert scale: 1. Strongly disagree, 2. Disagree 3. Somewhat disagree, 4. Neither agree or disagree, 5. Somewhat agree, 6. Agree, 7. Strongly agree. A summary of the results is presented in Table 8 .

\section{Table 8}

Student Attitudes towards English

\begin{tabular}{lcc}
\hline \multicolumn{1}{c}{ Item } & Mean & $S D$ \\
\hline I would find mobile technology (MT) useful in my English language learning & 5.4 & 1.83 \\
Mobile technology would enable me to access English language learning content & 5.2 & 1.72 \\
more quickly & 5.2 & 1.69 \\
Mobile technology will enable me to access English language learning content & & \\
more often & 5.0 & 1.81
\end{tabular}

efficient way to utilize my time 
Factors influencing Preparatory Year students' skills and attitudes in the use of mobile devices in EFL

Table 8 ... continued

\begin{tabular}{|c|c|c|}
\hline Item & Mean & $S D$ \\
\hline $\begin{array}{l}\text { I believe it would be more convenient to access English language learning content } \\
\text { via a mobile device over using a computer }\end{array}$ & 4.8 & 1.77 \\
\hline $\begin{array}{l}\text { I believe that it would take me longer to accomplish English language learning } \\
\text { tasks using a mobile device* }\end{array}$ & 4.0 & 1.87 \\
\hline $\begin{array}{l}\text { I believe I would find it easy to use a mobile device to support my English } \\
\text { language learning }\end{array}$ & 4.9 & 1.73 \\
\hline $\begin{array}{l}\text { I think it might take me a while to get comfortable with using a mobile device for } \\
\text { English language learning* }\end{array}$ & 4.3 & 1.83 \\
\hline $\begin{array}{l}\text { I feel that I would have the knowledge necessary to use mobile devices to support } \\
\text { my English language learning }\end{array}$ & 4.9 & 1.74 \\
\hline Using mobile technology would not be compatible with the way I learn English* & 4.2 & 1.79 \\
\hline $\begin{array}{l}\text { I believe I would be more willing to use mobile technology for my English } \\
\text { language learning if I had support if I needed help }\end{array}$ & 5.0 & 1.80 \\
\hline Using mobile technology for English language learning is a good idea & 5.1 & 1.79 \\
\hline Mobile technology will make learning English more interesting & 5.1 & 1.80 \\
\hline Working with mobile technology will be fun & 5.2 & 1.74 \\
\hline $\begin{array}{l}\text { I would be anxious about having to use my mobile device to support my English } \\
\text { language learning* }\end{array}$ & 3.9 & 1.91 \\
\hline $\begin{array}{l}\text { I would be concerned if using my mobile device was a required component of my } \\
\text { English language study* }\end{array}$ & 3.9 & 1.94 \\
\hline Currently using a mobile device and the associated services are too expensive* & 4.5 & 1.74 \\
\hline $\begin{array}{l}\text { Overall, I think using mobile technology would be beneficial to my English } \\
\text { language learning and I would be willing to adopt it in the future }\end{array}$ & 5.1 & 1.86 \\
\hline Overall & 4.6 & 0.84 \\
\hline
\end{tabular}

Note. * Reverse-coded item

In general, students displayed positive attitudes towards using mobile technology in English language learning. The item with the highest mean was I would find mobile technology (MT) useful in my English language learning (5.4). A strong majority of students (75\% - Strongly agree, Agree, Somewhat agree) were in agreement with this item with $16.2 \%$ of students disagreeing (i.e., Strongly disagree, Disagree, Somewhat disagree). Three items had the second highest mean (5.2): Mobile technology would enable me to access English language learning content more quickly, Mobile technology will enable me to access English language learning content more often, and Working with mobile technology will be fun. All responses reflecting the convenience and enjoyment students find with using mobile technology. Two items had the lowest mean (3.9): I would be anxious about having to use my mobile device to support my English language learning and I would be concerned if using my mobile device was a required component of my English language study. Nevertheless, more than one-third of students (39.4\% - Strongly agree, Agree, Somewhat agree) believed they would be anxious having to use their mobile devices to support their English language learning. Similarly, more than one-third of students (38.8\% - Strongly agree, Agree, Somewhat agree) believed they would be concerned if using mobile devices was a required component of English language study.

\subsection{Future intention to us mobile devices in English language learning}

Students were asked about their future intentions to use mobile devices in their English language learning. Future intention was assessed using a seven-point Likert scale: 1. Strongly disagree, 2. Disagree 3. Somewhat disagree, 4. Neither agree or disagree, 5. Somewhat agree, 6. Agree, 7. Strongly agree. A summary of the results is presented in Table 9. 
Alshammari, R., Parkes, M., \& Adlington, R.

Table 9

Future intentions to use mobile devices in English language learning

\begin{tabular}{|c|c|c|}
\hline Item & Mean & $S D$ \\
\hline $\begin{array}{l}\text { I would like to see mobile technology incorporated into my English language } \\
\text { learning classes. }\end{array}$ & 4.9 & 1.97 \\
\hline $\begin{array}{l}\text { I would like to be able to easily view my English language learning course } \\
\text { materials (syllabus, notes, assignments) on my mobile device. }\end{array}$ & 5.0 & 1.81 \\
\hline $\begin{array}{l}\text { I would like to be able to access Learning Management Systems (e.g. Moodle, } \\
\text { Blackboard) for English language learning on my mobile device. }\end{array}$ & 5.0 & 1.83 \\
\hline $\begin{array}{l}\text { I would like to be able to take quizzes for my English language learning on my } \\
\text { mobile device. }\end{array}$ & 5.0 & 1.86 \\
\hline $\begin{array}{l}\text { I would like to be able to participate in discussion forums for my English language } \\
\text { learning from my mobile device. }\end{array}$ & 4.9 & 1.91 \\
\hline Overall & 4.9 & 1.61 \\
\hline
\end{tabular}

Overall, students responded relatively positively towards using mobile devices into their future English language classes with all survey items having similar mean scores. Students expressed similar sentiments with respect to the four survey items focused on the practical application of mobile technologies in English language learning: I would like to be able to easily view my English language learning course materials (syllabus, notes, assignments) on my mobile device, I would like to be able to access Learning Management Systems (e.g. Moodle, Blackboard) for English language learning on my mobile device, I would like to be able to participate in discussion forums for my English language learning from my mobile device, and I would like to be able to take quizzes for my English language learning on my mobile device. When asked whether they would like to see mobile technology incorporated into their English language learning, the majority of students $(61.3 \%)$ were in agreement (i.e., strongly agree, agree, somewhat agree). However, close to one-quarter of students $(23.4 \%)$ disagreed with this statement (i.e., strongly disagree, disagree, somewhat disagree) and $15.3 \%$ of students neither agreed or disagreed. So, despite an overall positive sentiment in general about their future intentions to use mobile technology in English language learning, a reasonable proportion of students appear hesitant about future use of mobile devices in their English language learning.

\subsection{Pearson product-moment correlations}

Pearson product-moment correlation coefficients is a standardized measure of the strength of a relationship between variables (Field, 2005). Average student responses for each of the seven scale items were computed to form seven new variables: overall computer skills, overall Internet skills, overall mobile device skills, overall student attitudes towards ICT, overall student attitudes towards English, overall student attitudes towards using mobile technology in English language learning, and overall future intention to use mobile devices in English language learning. Pearson product-moment correlation coefficients were computed to assess the relationship between these seven sets of variables to determine if there were any statistically significant correlations between them. Of particular interest were the three target variables associated with mobile technologies and their use to support English Language learning: overall mobile device skills, overall student attitudes towards using mobile technology in English language learning and overall future intention to use mobile devices in English language learning. Table 10 presents the results of this analysis. 
Table 10

Correlations table

\begin{tabular}{|c|c|c|c|c|c|c|}
\hline & $\begin{array}{c}\text { Overall } \\
\text { Internet } \\
\text { skills }\end{array}$ & $\begin{array}{l}\text { Overall } \\
\text { mobile } \\
\text { device } \\
\text { skills }\end{array}$ & $\begin{array}{l}\text { Overall } \\
\text { ICT } \\
\text { attitudes }\end{array}$ & $\begin{array}{l}\text { Overall } \\
\text { English } \\
\text { attitudes }\end{array}$ & $\begin{array}{l}\text { Overall } \\
\text { attitudes } \\
\text { using } \\
\text { mobile } \\
\text { devices in } \\
\text { English }\end{array}$ & $\begin{array}{c}\text { Overall } \\
\text { future } \\
\text { intention to } \\
\text { use mobile } \\
\text { devices in } \\
\text { English }\end{array}$ \\
\hline Overall computer skills & $.515^{*}$ & $.301 *$ & $.422 *$ & $.153 *$ & $.254 *$ & $.210 *$ \\
\hline Overall Internet skills & & $.634 *$ & $.636^{*}$ & $.261 *$ & $.437 *$ & $.351 *$ \\
\hline Overall mobile skills & & & $.445^{*}$ & $.223 *$ & $.390 *$ & $.336 *$ \\
\hline Overall ICT attitudes & & & & $.313^{*}$ & $.570 *$ & $.417 *$ \\
\hline \multicolumn{5}{|c|}{ Overall attitudes towards English } & $.416^{*}$ & $.321 *$ \\
\hline \multicolumn{4}{|c|}{ Overall attitudes towards using mobile devices in English } & $.600 *$ & & \\
\hline
\end{tabular}

Note. * Correlation is significant at the .01 level (2-tailed)

All variables returned statistically significant correlations although the strength of association varied. For the three target variables strong positive correlations (i.e., $r$ between .5 and 1.0) were found between three pairs of items:

> Overall mobile device skills and overall Internet skills $(\mathrm{r}=.634)$;

> Overall attitudes towards using mobile devices in English and Future intention to use mobile devices in English language learning $(\mathrm{r}=.600)$;

Overall attitudes towards using mobile devices in English and overall ICT attitudes $(\mathrm{r}=.570)$.

For the three target variables, moderate positive correlations (i.e., $\mathrm{r}$ between .3 and.5) were identified between seven pairs of variables:

Overall mobile device skills and overall ICT attitudes $(\mathrm{r}=.445)$;

Overall attitudes towards using mobile devices in English and overall attitudes towards English $(\mathrm{r}=.416)$;

Overall mobile device skills and overall attitudes towards using mobile devices in English (r $=.390)$;

Overall future intention to use mobile devices in English language learning and overall Internet skills $(\mathrm{r}=.351)$;

Overall mobile device skills and overall future intention to use mobile devices in English language learning $(\mathrm{r}=.336)$;

Overall future intention to use mobile technology in English language learning and overall attitudes towards English $(\mathrm{r}=.321)$;

Overall mobile device skills and overall computer skills $(\mathrm{r}=.301)$.

\subsection{Independent samples $t$-tests}

An independent-sample t-test is a statistical technique used to determine whether significant differences exist between two groups of sample respondents for a single dependent variable (Cooksey, 2007). 
Alshammari, R., Parkes, M., \& Adlington, R.

Independent-sample t-tests were used to determine if any significant differences for the three computed target variables: overall mobile device skills, overall student attitudes towards using mobile technology in English language learning and overall future intention to use mobile devices in English language learning, and students' place of residence (i.e., urban or rural). The results of this analysis are presented in Table 11.

Table 11

Independent samples t-tests results

\begin{tabular}{lccccccc}
\hline \multicolumn{1}{c}{ Item } & \multicolumn{9}{c}{ Urban $(\mathrm{N}=386)$} & \multicolumn{2}{c}{ Rural $(\mathrm{N}=35)$} & & & \\
& Mean & SD & Mean & SD & $t$ & $p$ & Cohen's $d$ \\
\hline Overall mobile device skills & 5.8 & 1.50 & 4.6 & 1.97 & 3.51 & .001 & .78 \\
Overall student attitudes to use mobiles & 4.6 & 0.81 & 4.2 & 1.01 & 2.19 & .036 & .48 \\
Overall intention to use mobile technology & 5.0 & 1.57 & 4.3 & 1.86 & 2.47 & .014 & .46 \\
\hline
\end{tabular}

Statistically significant differences between urban and rural students were identified for all three target variables. A student's place of residence was shown to influence mobile device skill; attitudes towards using mobile devices in English language learning; and future intention to use mobile devices in their English language learning. Cohen's $d$ for overall mobile device skills reported a medium effect size (i.e., $>.5$ and $<.8$ ) with small effect sizes (i.e., $>.2$ and <.5) for both overall student attitudes towards using mobile technology in English language learning and overall future intention to use mobile devices in English language learning.

\subsection{One-way Analysis of Variance}

Analysis of Variance (ANOVA) is a statistical technique used to determine whether significant differences exist between three or more means (Bryman \& Cramer, 2005). ANOVA was used on to determine if there were any statistically significant differences for the three target variables: overall mobile device skills, overall student attitudes towards using mobile technology in English language learning and overall future intention to use mobile devices in English language learning, and the demographic variables: age, Preparatory Year path, and level of English studied.

For age, no statistically significant differences were identified for the three target variables analyzed. Thus, age did not significantly influence students' overall mobile device skills, overall attitudes towards using mobile technology in English language learning, or overall future intention to use mobile devices in English language learning.

For Preparatory Path, statistically significant differences were identified for two of the three target variables. First, for overall attitudes towards using mobile technology in English language learning, a statistically significant difference was identified between the overall means of students in the three different Preparatory Year paths: $\mathrm{F}(2,398)=7.09, p=.001$. Post hoc comparisons using the Bonferroni test indicated that the mean score of students in both the Medical $(M=4.9, S D=.78)$ and Engineering and Science paths $(M=4.7, S D=0.85)$ were significantly different to students in the Humanities path $(\mathrm{M}=4.3, \mathrm{SD}=.76)$. However, the mean score for students in the Medical path did not differ significantly from the mean score of students in the Engineering and Science path. The value of partial eta square calculated (.034) indicated a small effect size and so this relationship is of little practical significance.

Second, for overall future intention to use mobile devices in English language learning, a statistically significant difference was identified between the overall means of students in the three different Preparatory Year paths: $\mathrm{F}(2,395)=6.30, p=.002$. Post hoc comparisons using the Bonferroni test indicated that the mean score of students in the Engineering and Science path $(\mathrm{M}=5.1, \mathrm{SD}=1.6)$ was significantly different to students in the Humanities path $(\mathrm{M}=4.3, \mathrm{SD}=1.70)$. However, the mean score for students in the Medical path $(\mathrm{M}=5.1$, $\mathrm{SD}=1.17$ ) did not significantly differ from the mean score of students in the Engineering and Science path or the mean score of students in the Humanities path. The effect size of this relationship was only small with a 
partial eta value of .031 and therefore of little practical significance.

For the variable, overall mobile device skills, no statistically significant differences were identified between students in the three different Preparatory Year paths (Medical, Humanities, and Engineering and Science). Therefore, Preparatory Year path had no influence on students' overall level of mobile device skills.

For level of English, a statistically significant difference was identified between the overall means of students in the four different levels of English (Level 1, Level 2, Level 3, and Level 4) for the target variable, overall attitudes towards using mobile technology in English language learning: $\mathrm{F}(3,394)=3.35, p=.019$. However, post hoc comparisons using the Bonferroni test were unable to identify any statistically significant differences between the mean scores of students in the four levels of English. The Bonferroni test is conservative, and while the probability of a Type I error is low, it does run the risk of rejecting differences between means that may be statistically significant (Field, 2005). When the ANOVA was repeated using the less conservative post hoc test Hochsberg's GT2, this test was also unable to identify any statistically significant differences between the mean scores of students in the four levels of English. To prevent the possibility of a Type I error (i.e., false positive), the decision was made that there were no statistically significant differences for level of English for overall attitudes towards using mobile technology in English language learning.

For the other target variables, overall mobile device skills and overall future intention to use mobile devices in English language learning, no statistically significant differences were identified between students in the four different levels of English. Therefore, the level of English studied had no influence on students' overall future intention to use mobile devices in English language learning.

\section{Discussion}

\subsection{Student mobile device skills}

Students self-reported high levels of mobile device skills with the overall mean score of mobile device skills $(\mathrm{M}=5.7)$ being higher than the overall mean score of both computer skills $(\mathrm{M}=3.2)$ and Internet skills $(\mathrm{M}=$ 4.4). This could be explained by most students knowing how to use mobile devices and using them on a daily basis (Khwaileh \& Al-Jarrah, 2010).

For mobile device skills, the highest mean scores were for activities associated with personal communication (sending SMS, calling, and sending pictures or movies to other people). This is not surprising as the mobile device's original purpose was for personal communication. Another strength of mobile devices is their utility. This was reflected in the broad range of activities with the next highest means: downloading and playing games and applications; taking pictures or movies; and accessing information and services from on the web.

Student overall mobile device skills were shown to be strongly positively correlated with student Internet skills $(\mathrm{r}=.634, p<.001)$. While drawing conclusions from the results of correlation should be made with caution, there is evidence to suggest that the correlation between these two items is causal. As smartphones are Internet-enabled devices, many of the Internet activities surveyed could also be executed on mobile devices. Hence, a strong positive correlation is likely to have be expected between these two sets of skills. A moderate positive correlation was identified between students' overall mobile device skills and their overall computer skills $(\mathrm{r}=.301, p<.001)$. In this case, a number of the computer skills surveyed, while executable on mobile devices, to date have been not widely done so, for example, editing audio and video or manipulating digital photos. Such transformations might possibly be best left to computers than mobile devices. Hence, these two sets of skills might be expected to be more weakly correlated.

Results from the t-test indicated that place of residence (urban or rural) did influence students' level of mobile device skills. Cohen's $d(.78)$ fell in the medium effect range, suggesting this result is of practical 
significance. Students from urban areas considered themselves to more skilled in the use of mobile devices than students from rural areas. Inspection of mean scores for both overall computer skills and overall Internet skills gave similar findings - students from urban area considered themselves to be more skilled than their rural counterparts. One possible explanation might be a lack of previous exposure to these technologies. Prior to their university Preparatory Year, students would have attended school at their places of residence. However, there is often a large disparity in the provision of ICT infrastructure amongst Saudi Arabian schools. For example, Alresheed, Leask, and Raiker (2015) reported that $80 \%$ of teachers did not have Internet access in their classrooms. Further, under half the teachers $(45.5 \%)$ reported having access to computer laboratories, while just under a third of teachers had access to Wi-Fi technologies. ICT infrastructure is lacking in many schools in Saudi Arabia and there have been calls to increase the technological infrastructure - especially in schools in rural areas (Aljuaid, 2016). Having less exposure to these technologies could explain why rural students in particular, feel less confident and consider themselves to be less skilled in the use of computers, the Internet and mobile devices, than urban students.

Results from ANOVA indicated that age, Preparatory Year path and level of English studied did not significantly influence students' overall mobile device skills. This might be considered further evidence of the universality of mobile devices. The practical implication of these results, from the perspective of the study site, is that if the formal use of mobile devices in English language instruction was introduced at the study site, then demographically, no particular set of students would be overly advantaged or disadvantaged. ANOVA results for overall computer skills and overall Internet skills, yielded no significant differences for mean scores between students of different ages. However, ANOVA did yield a statistically significant difference for overall Internet skills between students in the different Preparatory Year paths: $\mathrm{F}(2,418)=11.00, p<.001$. Statistically significant differences were also found between students in the different levels of English studied for both computer skills: $\mathrm{F}(3,414)=4.96, p=.002$, and Internet skills: $\mathrm{F}(3,414)=3.75, p=.011$ but not for mobile device skills. With respect to the study site, from an equity perspective, using mobile devices as the preferred a teaching tool, could address some of the imbalances evident due to the differing computer and Internet skills sets amongst students.

\subsection{Student attitudes towards using mobile devices in English language learning}

For student attitudes towards using mobile devices in English language learning, the survey items with the highest means scores, I would find mobile technology (MT) useful in my English language learning; mobile technology would enable me to access English language learning content more quickly; and mobile technology will enable me to access English language learning content more often, reflect the utility and convenience of mobile devices in education. This supports findings from a range of previous studies of the usefulness of mobile devices in language learning contexts (e.g., Bezircilioğlu, 2016; Qudah et al., 2013; Khrisat \& Mahmoud, 2013; Nalliveettil \& Alenazi, 2016).

Taking into account the contextual factors of the study site, one noteworthy result was for the item: I believe it would be more convenient to access English language learning content via a mobile device over using a computer. At the study site, while students have access to computers as part of their formal English language learning, the use of mobile technologies is not officially endorsed. However, the majority of students $(62 \%$ Strongly agree, Agree, Somewhat agree) believed that mobile devices would be more convenient to use to access their English language learning content, while only 19.8\% disagreed (i.e., Strongly disagree, Disagree, Somewhat disagree). Just under one-fifth of students (18\%) remained unsure. This suggests a reasonably strong preference of the students to use mobile devices over computers for their English language learning.

Student overall attitudes towards using mobile devices in English language learning were shown to be strongly positively correlated with both future intentions to use mobile devices in English language learning ( $\mathrm{r}$ $=.600, p<.001)$ and overall ICT attitudes $(\mathrm{r}=.570, p<.001)$. The relationship between positive attitudes towards a technology and the behavioral intention to adopt its use has been well documented in the literature 
Factors influencing Preparatory Year students' skills and attitudes in the use of mobile devices in EFL

through the Technology Acceptance Model (TAM). Put simply, if students are positively inclined towards technology then they are more likely to use it (Huang, Lin, \& Chuang, 2007). The strong positive relationship between overall attitudes towards using mobile devices in English language learning and future intention to use mobile devices in English language learning lends further support this concept. From the evidence presented, it also appears that students who are positively inclined to ICT in general also hold positive attitudes towards the use of mobile devices in English language learning in particular.

It is also worth noting that overall attitudes towards using mobile devices in English language learning were only moderately correlated with overall mobile device skills $(\mathrm{r}=.390, p<.001)$ and overall attitudes towards English $(\mathrm{r}=.416, p<.001)$ This suggests that students did not necessarily require high levels of mobile device skills or strong positive attitudes towards English to be positively inclined to using mobile devices to support their English language learning.

Similarly, for mobile device skills, t-test results indicated that place of residence (urban or rural) was shown to influence attitudes towards using mobile devices in English language learning. Overall, students whose respective places of residence were in urban areas displayed more positive attitudes towards the use of mobile devices to support English language learning than students from rural areas. However, Cohen's d (.48) fell in the small effect range, indicating that this result was of little practical significance.

Results from ANOVA indicated that students' attitudes towards the use of mobile devices to support English language learning were not significantly different for age and level of English studied. The value of partial eta squared for Preparatory Year path indicated that this variable was of little practical significance. Thus, from a practical perspective, age, Preparatory Year path, and level of English study had little, if any, influence on students' attitudes towards the use of mobile devices to support English language learning. These results support similar findings that the demographic factors: age (Qudah et al., 2013; Al-Emran et al., 2016; Yorganci, 2017), academic discipline (Taleb \& Sohrabi, 2012), and level of study (Al-Emran et al., 2016) do not significantly influence student attitudes towards mobile devices.

\subsection{Future intention to use mobile devices in English language learning}

Overall, the majority of students signaled their willingness to use mobile devices in their English language learning in the future. Despite this positive result, nevertheless close to one-quarter of students disagreed with the statement: I would like to see mobile technology incorporated into my English language learning classes. So, student future intention to use mobile devices was not unanimous. Examining the correlations between the scale item, overall future intention to use mobile devices in English language learning and the various other scale items could assist identifying the critical factors influencing student willingness to use mobile devices in the future.

Following this line of reasoning, overall future intention to use mobile devices in English language learning was most strongly positively correlated with overall attitudes towards using mobile devices in English $(\mathrm{r}=.600$, $p<.001$, Table 10.). Comparison of the frequency distributions between these two scale items gives a possible insight into the nature of this correlation. For overall attitudes towards using mobile devices in English, over one-third of students expressed a degree of anxiety towards both having to use their mobile devices to support their English language learning and using mobile devices for English language study if it became a required component. For future intention to use mobile devices in English language learning, when asked whether they would like to see mobile technology incorporated into their English language learning, close to one-quarter of students disagreed with this statement. As discussed earlier, the relationship between positive attitudes towards a technology and the behavioral intention to adopt its use is well documented through the Technology Acceptance Model (TAM). Taking the TAM into account for these two sets of scale items - one of which is attitudinal (i.e., overall attitudes towards using mobile devices in English) and the other which represents a behavioral intention (i.e., overall future intention to use mobile devices in English language learning) - it is reasonable to suggest that 
for some of the students it may be anxiety over the use of mobile devices which may be driving these negative attitudes towards using mobile devices in English language learning which in turn impacts on their behavioral intention to use mobile devices in their English language learning in the future.

The implication is that although the majority of Preparatory Year students at the study site expressed positive attitudes towards mobile devices in English language learning and are positively inclined to use it in the future, precautions should be taken to address the anxiety some students feel towards the implementation and required use of mobile devices if it were to occur at some point in the future. Addressing this anxiety should lead to more positive attitudes towards the use of mobile devices in English language learning which in turn should results in a greater willingness to use mobile devices in the future English language learning.

As for mobile device skills and attitudes towards using mobile devices in English language learning, t-test results indicated that place of residence (urban or rural) was shown to influence students' overall future intention to use mobile devices in English language learning. In general, students whose places of residence were urban areas had a significantly higher overall future intention to use mobile devices in English language learning than students from rural areas. However, as for overall attitudes towards using mobile devices in English, Cohen's d (0.47) fell in the small effect range, suggesting that this result is of little practical significance.

Results from ANOVA indicated that students' future intention to use mobile devices in English language learning were not significantly different for age or level of English, but they were significantly different for Preparatory Year path. However, the value of partial eta squared for Preparatory Year path indicated that the influence of this variable was of little practical significance.

The non-significant results for age and level of English plus the result of little practical significance for Preparatory Year path suggest that future intentions to use mobile devices in English language learning will not be unduly influenced by these demographic variables. This is an encouraging result for the study site in particular as it provides further evidence that if mobile devices were adopted in English language instruction then no particular student from any particular age, Preparatory Year path or level of English studied would be unduly advantaged or disadvantaged.

\section{Conclusion}

\subsection{Key findings}

The aim of the study was to identify factors that might influence Preparatory Year students' use of mobile technology in English language learning for three target variables:

$>$ mobile device skill;

$>\quad$ attitudes towards using mobile devices in English language learning;

$>\quad$ and future intention to use mobile devices in English language learning.

A student's age, Preparatory Year path or level of English being studied did not significantly influence their overall mobile device skills. This aligns with the findings of studies in similar contexts to this current study (e.g., Al-Emran et al., 2016; Taleb \& Sohrabi, 2012). Of further interest is that neither Preparatory Year path nor level of English studied influenced overall mobile device skills. This new understanding provides further evidence of the universality and ease of use of mobile devices, and supports the case for the adoption of mobile devices for English language learning, particularly because doing so would not disadvantage students based on their level of English.

Overall, mobile device skill level for Preparatory Year students was higher than both overall computing and Internet skill levels. The majority of students also showed more positive attitudes towards using mobile devices 
Factors influencing Preparatory Year students' skills and attitudes in the use of mobile devices in EFL

(compared with computers), and therefore a preference, to using mobile devices over computers for their English language learning. Further, while computing and Internet skills were influenced by the demographic variables, mobile skills were not. From the perspective of the study site, if mobile devices were adopted in preference to computers, not only would students readily them, existing demographic-based inequalities would also be reduced.

Student overall attitudes towards using mobile devices in English language learning were strongly positively correlated with both future intentions to use mobile devices in English language learning and overall ICT attitudes. The strong correlation between overall attitudes towards using mobile devices and future intention to use provide further support of the influence attitudes can play in the decision to use technology (Huang, Lin \& Chuang, 2007).

Student overall attitudes towards using mobile devices in English language learning were only moderately correlated with overall mobile device skills and overall attitudes towards English. In other words, students did not necessarily require a high levels of mobile device skills or strong positive attitudes towards English to be willing to use mobile devices to support their English language learning. This is further evidence that students would positively respond to the adoption of mobile devices for English language learning.

From a practical perspective, age, Preparatory Year path, and level of English study had little if any influence on students' students' future intention to use mobile devices in English language learning. This 'equality of attitudes' towards mobile devices was previously identified by Qudah et al. (2013), with respect to gender. The authors attributed this alignment of perspectives between males and females being to both groups having the same need to use mobile devices in their university education. Similarly, results from the current study suggest that irrespective of age, Preparatory Year path, or level of English studied, students do not significantly differ in their willingness to use mobile devices in their English language learning.

Finally, despite the range of non-significant findings, student place of residence (urban or rural) was shown to influence level of mobile device skills, attitudes towards using mobile devices in English language learning, and future intention to use mobile devices in English language learning. In all instances, students from urban areas rated themselves higher than their rural counterparts. However, the influence of place of residence on level of mobile device skill was shown to be the only effect of any real practical significance. Differences in mobile skills between urban and rural students may be due to a relative lack of general mobile device familiarity for this cohort, and also familiarity with the potential of mobile devices for English language learning.

\subsection{Study limitations}

This study has a number of limitations. First, the data collected was limited to the one study site. Research needs to be conducted at a number of other study sites to help improve the generalizability of the study's results. Second, the study population was restricted to students in their Preparatory Year. Sampling students at other levels of their university studies would also assist in improving the generalizability of the study's results. Third, as is the norm in Saudi Arabia, the university study site is segregated by sex. The current study only captured the perspectives of male students. The perspectives of female students should also be sought to further improve the generalizability of the study's results.

\section{References}

Al-Emran, M., Elsherif, H. M., \& Shaalan, K. (2016). Investigating attitudes towards the use of mobile learning in higher education. Computers in Human Behavior, 56, 93-102. https://dx.doi.org/10.1016/j.chb.2015.11.033

Aljuaid, H. (2016). Technology in education between Saudi Arabia and the US: The interactive whiteboard and iPad (Doctoral dissertation). Retrieved from https://search.proquest.com/docview/1814765470?pq-origsite=gscholar 
Almarwani, M. A. (2011). ML for EFL: rationale for mobile learning. Paper presented at the International Conference of ICT for Language Learning 4th Edition.

Alresheed, S., Leask, M., \& Raiker, A. (2015). Integrating computer-assisted language learning in Saudi schools: A change model. The Turkish Online Journal of Educational Technology, 14(4), 69-77.

Alshammari, R., Parkes, M., \& Adlington, R. (2017). Using WhatsApp in EFL instruction with Saudi Arabian university students. Arab World English Journal, 8(4), 68-84. https://dx.doi.org/10.24093/awej/vol8no4.5

Al-shehri, S. (2012). Contextual language learning: The educational potential of mobile technologies and social media. (Doctoral dissertation). Retrieved from http://espace.library.uq.edu.au/view/UQ:284464

Bezircilioğlu, S. (2016). Mobile assisted language learning. Journal of Educational and Instructional Studies in the World, 6, 9-12.

Bryman, A., \& Cramer, D. (2005). Quantitative data analysis with SPSS: A guide for social scientists. London: Routledge.

Cavus, N., \& Ibrahim, D. (2009). m-Learning: An experiment in using SMS to support learning new English language words. British Journal of Educational Technology, 40(1), 78-91. https://doi.org/10.1111/j.1467-8535.2007.00801.x

Chen, K.T.-C. (2016). Examining EFL instructors' and students' perceptions and acceptance toward m-learning in higher education. Universal Access in the Information Society, 16(4), 967-976. https://doi.org/10.1007/s10209-016-0494-8

Clough, G., Jones, A.C., McAndrew, P., \& Scanlon, E. (2008). Informal learning with PDAs and smartphones. Journal of Computer Assisted Learning, 24(5), 359-371. https://doi.org/10.1111/j.1365-2729.2007.00268.x

Comas-Quinn, A., Mardomingo, R., \& Valentine, C. (2009). Mobile blogs in language learning: Making the most of informal and situated learning opportunities. ReCALL, 21(1), 96-112. http://dx.doi.org/10.1017/S0958344009000032

Cooksey, R. W. (2007). Illustrating statistical procedures: Finding meaning in quantitative data (2nd ed.). Victoria, Australia: Tilde publishing and distribution.

Field, A. (2005). Discovering statistics using SPSS (2nd ed.). London: Sage.

Haight, M., Quan-Haase, A., \& Corbett, B. A. (2014). Revisiting the digital divide in Canada: the impact of demographic factors on access to the Internet, level of online activity, and social networking site usage. Information, Communication \& Society, 17(4), 503-519. https://doi.org/10.1080/1369118X.2014.891633

Hong, Y. A., Zhou, Z., Fang, Y., \& Shi, L. (2017). The digital divide and health disparities in China: Evidence from a national survey and policy implications. Journal of Medical Internet Research, 19(9). https://doi.org/10.2196/jmir.786

Huang, J. H., Lin, Y. R., \& Chuang, S. T. (2007). Elucidating user behavior of mobile learning: A perspective of the extended technology acceptance model. The Electronic Library, 25(5), 585-598. https://doi.org/10.1108/02640470710829569

Khrisat, A. A., \& Mahmoud, S. S. (2013). Integrating mobile phones into the EFL Foundation Year classroom in King Abdulaziz University/KSA: Effects on achievement in general English and students' attitudes. English Language Teaching, 6(8), 162-174. https://doi.org/10.5539/elt.v6n8p162

Khwaileh, F. M., \& Al-Jarrah, A. (2010). Graduate students' perceptions toward mobile-learning (M-Learning) at the University of Jordan. International Journal of Instructional Technology and Distance Learning, $7(10), 15-23$

Kukulska-Hulme, A. (2009). Will mobile learning change language learning? ReCALL, 21(2), 157-165. https://doi.org/10.1017/S0958344009000202

Levy, M., \& Kennedy, C. (2005) Learning Italian via mobile SMS. In A. Kukulska-Hulme \& J. Traxler (Eds.), Mobile learning: A handbook for educators and trainers (pp. 76-83). London, England: Taylor \& Francis.

Librero, F., Ramos, A. J., Ranga, A. I., Triñona, J., \& Lambert, D. (2007). Uses of the cell phone for education 
Factors influencing Preparatory Year students' skills and attitudes in the use of mobile devices in EFL

in the Philippines and Mongolia. Distance Education, 28(2), 231-244.

https://doi.org/10.1080/01587910701439266

Lu, M. (2008). Effectiveness of vocabulary learning via mobile phone. Journal of Computer Assisted Learning, 24(6), 515-525. https://doi.org/10.1111/j.1365-2729.2008.00289.x

Mac Callum, K. S. (2011). Influences on the adoption of mobile technology by students and teachers (Doctoral dissertation). Massey University, Albany, New Zealand. Retrieved from http://hdl.handle.net/10179/3684

Mac Callum, K., \& Jeffrey, L. (2013). The influence of students' ICT skills and their adoption of mobile learning. Australasian Journal of Educational Technology, 29(3), 303-314. https://doi.org/10.14742/ajet.298

Nalliveettil, G. M., \& Alenazi, T. H. K. (2016). The impact of mobile phones on English language learning: Perceptions of EFL undergraduates. Journal of Language Teaching and Research, 7(2), 264-272. https://doi.org/10.17507/jltr.0702.04

Park, S., \& Kim, G. (2015). Same access, different uses, and the persistent digital divide between urban and rural internet users, TPRC 43: The 43rd Research Conference on Communication, Information and Internet Policy Paper. September 23-25, 2015, Arlington, Virginia.

Pénard, T., Poussing, N., Zomo Yebe, G., \& Ella, N. (2012). Comparing the determinants of internet and cell phone use in Africa: evidence from Gabon. Communication \& Strategies, 86(2), 65-83.

Pollara, P. (2011). Mobile learning in higher education: A glimpse and a comparison of student and faculty readiness, attitudes and perceptions (Doctoral dissertation). Duquesne University. Retrieved from http://etd.1su.edu/docs/available/etd-11042011-105812/

Qudah, K., Hussain, J.A., \& Al Matari, R. (2013). Students' attitudes in colleges of education at the Jordanian universities towards mobile phone usage in university education. International Journal of Interactive Mobile Technologies, 7(2), 19-28. http://dx.doi.org/10.3991/ijim.v7i2.2286

Saidouni, K., \& Bahloul, A. (2016). Teachers and students' attitudes towards using mobile-assisted language learning in higher education. Arab World English Journal, 3(3), 123-140.

Saran, M., Cagiltay, K., \& Seferoglu, G. (2008). Use of mobile phones in language learning: Developing effective instructional materials. In Fifth IEEE International Conference on Wireless, Mobile, and Ubiquitous Technology in Education, 2008. (pp. 39-43). Beijing, China: IEEE.

Stockwell, G. (2010). Using mobile phones for vocabulary activities: Examining the effect of the platform. Language learning \& technology, 14(2), 95-110.

Taleb, Z., \& Sohrabi, A. (2012). Learning on the move: The use of mobile technology to support learning for university students. Procedia - Social and Behavioral Sciences, 69, 1102-1109. http://dx.doi.org/10.1016/j.sbspro.2012.12.038

Uzunboylu, H., Hürsen, Ç., Özütürk, G., \& Demirok, M. (2015). Determination of Turkish university students' attitudes for mobile integrated EFL classrooms in North Cyprus and Scale Development: ELLMTAS. Journal of Universal Computer Science, 21(10), 1283-1296.

Viberg, O., \& Grönlund, A. (2013). Cross-cultural analysis of users' attitudes toward the use of mobile devices in second and foreign language learning in higher education: A case from Sweden and China. Computers \& Education, 69, 169-180. https://doi.org/10.1016/j.compedu.2013.07.014

Wang, F., Chen, X., \& Fang, W. (2011). Integrating cell Phones into a Chinese high school EFL Classroom: Students' attitudes, technological readiness, and perceived learning. Journal of Educational Technology Development and Exchange, 4(1), 91-102. https://doi.org/10.18785/jetde.0401.08

Yorganci, S. (2017). Investigating students' self-efficacy and attitudes towards the use of mobile learning. Journal of Education and Practice, 8(6), 181-185.

Yushau, B., \& Omar, M. H. (2007). Preparatory year program courses as predictors of first calculus course grade. Mathematics and Computer Education, 41(2), 92-108. 
Alshammari, R., Parkes, M., \& Adlington, R. 